\title{
УЛЬТРАСТРУКТУРНІ ЗМІНИ СУДИН ГЕМОМІКРОЦИРКУЛЯТОРНОГО РУСЛА ЗАДНІХ КІНЦІВОК ЩУРІВ ПРИ ГОСТРІЙ ІШЕМІї, ВИКЛИКАНІЙ НАКЛАДАННЯМ АРТЕРІАЛЬНОГО ТУРНІКЕТА
}

\author{
๑А. Т. Телев'як', П. Р. Сельський', І. М. Кліщ ${ }^{1}$, Р. С. Вастьянов ${ }^{2}$, О. Є. Кузів'1, \\ А. С. Вольська' ${ }^{1}$, Х. І. Курило ${ }^{1}$, І. І. Боймиструк', Б. П. Сельський ${ }^{3}$ \\ ${ }^{1}$ Тернопільський національний медичний університет імені І. Я. Горбачевського МОз України \\ ${ }^{2}$ Одеський національний медичний університет \\ ${ }^{3}$ Тернопільська університетська лікарня
}

РЕЗЮМЕ. Артеріальні турнікети широко використовуються як у військовій, так і в цивільній медицині (при пораненні кінцівок, артро-та ангіопластиках). Відновлення кровопостачання кінцівки після зняття турнікета може викликати ішемічно-реперфузійні ураження як первинно ішемізованих тканин, так і у віддалених тканинах та органах. Проте на сьогоднішній день ультраструктурні зміни тканин на місцевому рівні при ішемії-реперфузії потребують більш глибокого вивчення.

Мета роботи - дослідити стан гемомікроциркуляторного русла задніх кінцівок щурів при гострій ішемії та наступній реперфузії, викликаній накладанням артеріального турнікета.

Матеріал і методи. Проведено електронномікроскопічне дослідження судин гемомікроциркуляторного русла скелетних м'язів задніх кінцівок 12 щурів за умов експериментальної гострої ішемії. Контрольну групу склали 3 інтактних тварини. Гостру ішемію викликали шляхом накладання гумових джгутів SWAT шириною 5-6 мм на задні кінцівки тварин, на рівні пахвинної складки, протягом 2 год під тіопентал-натрієвим знеболюванням, а реперфузію моделювали шляхом зняття турнікета. Дослідження зразків м'язової тканини проводили на кафедрі гістології та ембріології Тернопільського національного медичного університету імені І. Я. Горбачевського за допомогою електронного мікроскопа ПЕМ-125К.

Результати. При електронній мікроскопії скелетних м'язів задніх кінцівок щурів у судинах гемомікроциркуляторного русла виявлено деструктивно змінені гемокапіляри з неоднаковою товщиною стінки, виражений набряк ендотеліоцитів із пролабуванням їх у просвіт гемокапілярів, десквамацію окремих ендотеліоцитів, потовщення базальної мембрани, розширені набряком периваскулярні простори, скупчення лімфоцитів у паравазальному просторі, появу білкових та еритроцитарних екстравазатів довкола гемокапілярів. Нерідко в просвіті судин поблизу ендотеліоцитів візуалізувалися тромбоцити, що свідчить про розвиток у гемокапілярах пристінкового мікротромбозу. Ультраструктурні зміни спостерігались вже через 2 години після зняття турнікета і були найбільше вираженими через 1 добу. У пізньому реперфузійному періоді відбувався зворотний розвиток патологічних змін, проте навіть через 14 діб реперфузії повного відновлення ультраструктури гемомікроциркуляторного русла все ще не відбувалося.

Висновки. Ультраструктурні порушення в судинах гемомікроциркуляторного русла ішемізованої м'язової тканини задніх кінцівок щурів досягали максимальної вираженості через 1 добу після зняття турнікета, що підтверджує розвиток у експериментальних тварин ішемічно-реперфузійного синдрому. У пізньому реперфузійному періоді відбувався зворотний розвиток патологічних змін.

КлючОВІ СлОВА: гостра ішемія; реперфузія; гемомікроциркуляторне русло; електронна мікроскопія.

Вступ. Артеріальні турнікети широко використовують як у військовій, так і в цивільній медицині (зокрема при пораненні кінцівок, артро- та ангіопластиках) [1-3]. Відновлення кровопостачання кінцівки після зняття турнікета може викликати ішемічно-реперфузійні ураження як первинно ішемізованих тканин, так і у віддалених органах [4-7]. Проте ультраструктурні зміни судин гемомікроциркуляторного русла при ішемічно-реперфузійному синдромі вивчені недостатHbO.

Мета - дослідити стан гемомікроциркуляторного русла скелетних м'язів задніх кінцівок щурів при гострій ішемії та наступній реперфузії, викликаній накладанням артеріального турнікета.
Матеріал і методи дослідження. Проведено електронномікроскопічне дослідження судин гемомікроциркуляторного русла (ГМЦР) скелетних м'язів задніх кінцівок 12 щурів за умов експериментальної гострої ішемії. У контрольній групі було 3 інтактних тварини.

Дослідження проведені 3 дотриманням основних положень «Правил проведення робіт 3 використанням експериментальних тварин», затверджених Указом МОЗ України № 753 від 12.08.1997 р., Конвенції Ради Європи про охорону хребетних тварин, які використовуються в експериментах та інших наукових цілях (1986), Указу МО3 України № 281 від 01.11.2000 р. «Про заходи з подальшого вдосконалення організаційних норм 
Огляди літератури, оригінальні дослідження, погляд на проблему, випадок з практики, короткі повідомлення роботи з використанням експериментальних тварин» та Закону України № 3447 - IV «Про захист тварин від жорстокого поводження» (2006).

Гостру ішемію викликали шляхом накладання гумових джгутів SWAT (Stretch-Wrap-And-Tuck) на задні праві кінцівки тварин шириною 5-6 мм на рівні пахвинної складки протягом 2 годин під тіопентал-натрієвим знеболюванням. Реперфузію моделювали шляхом відновлення кровообігу в раніше ішемізованих кінцівках після зняття турнікета.

Під час експерименту тварин було поділено на 4 дослідних групи. Модель раннього постішемічного періоду була представлена групами тварин із реперфузійними змінами через 2 години та 1 добу після зняття турнікета, а модель пізнього періоду - групами тварин із реперфузією через 7 та 14 діб (по 3 щури у кожній групі). Евтаназію тварин здійснювали шляхом декапітації під тіопентал-натрієвим знеболюванням.

Електронномікроскопічне дослідження проводили на кафедрі гістології та ембріології Тернопільського національного медичного університету імені І. Я. Горбачевського. Забір матеріалу (зразків ішемізованої м'язової тканини задніх кінцівок) проводили у відповідності до загальноприйнятої методики [8]. Фіксацію матеріалу здійснювали в 2,5 \% свіжоприготовленому розчині глютаральдегіду протягом години на фосфатному буфері Міллоніга (рН 7,3-7,4). Фіксований протягом 60 хвилин матеріал промивали у буферному розчині протягом 20-30 хвилин. Дофіксацію зразків здійснювали упродовж години 1 \% розчином оксиду осмію $\left(\mathrm{OsO}_{4}\right)$ на буфері Міллоніга. Дегідратацію проводили в спиртах наростаючої концентрації. Заливка досліджуваного матеріалу здійснювалася сумішшю епоксидних смол.

На ультрамікротомі LKB-3 (Швеція) виготовляли ультратонкі зрізи, які забарвлювали 1 \% водним розчином ураніл ацетату та контрастували цитратом свинцю за методом Рейнольдса. Отримані препарати вивчали і фотографували за допомогою електронного мікроскопа ПЕМ-125K.

Результати й обговорення. При аналізі електронномікроскопічних фотографій судин гемомікроциркуляторного русла (ГМЦР) скелетних м'язів задніх кінцівок інтактних щурів виявили, що гемокапіляри були правильної форми, їх стінки не потовщені, базальна мембрана чітко контурована, нормальної товщини та електронної щільності, ендотеліоцити звичайної форми та розмірів.

Через 2 години ішемічно-реперфузійного пошкодження тканин при електронномікроскопічному дослідженні судин ГМЦР скелетних м'язів задніх кінцівок щурів відмічалися набряк цитоплазми ендотеліоцитів, в якій збільшувалася

кількість кавеол та піноцитозних міхурців. Ядра ендотеліоцитів були овальної форми, з неглибокими та рідкими інвагінаціями, середньої електронно-оптичної щільності з рівномірно розподіленими гранулами хроматину по всій нуклеоплазмі. Гетерохроматин у вигляді вузької смужки локалізується вздовж внутрішнього листка нуклеолеми. Перинуклеарний простір звичайний, ядерні пори добре контуруються. У розширених периваскулярних просторах подекуди наявні невеликі осміофільні включення, а також значна кількість лімфоцитів, що свідчить про лімфоцитарну інфільтрацію м'яких тканин вже у перші години раннього періоду ішемії-реперфузії (рис. 1).

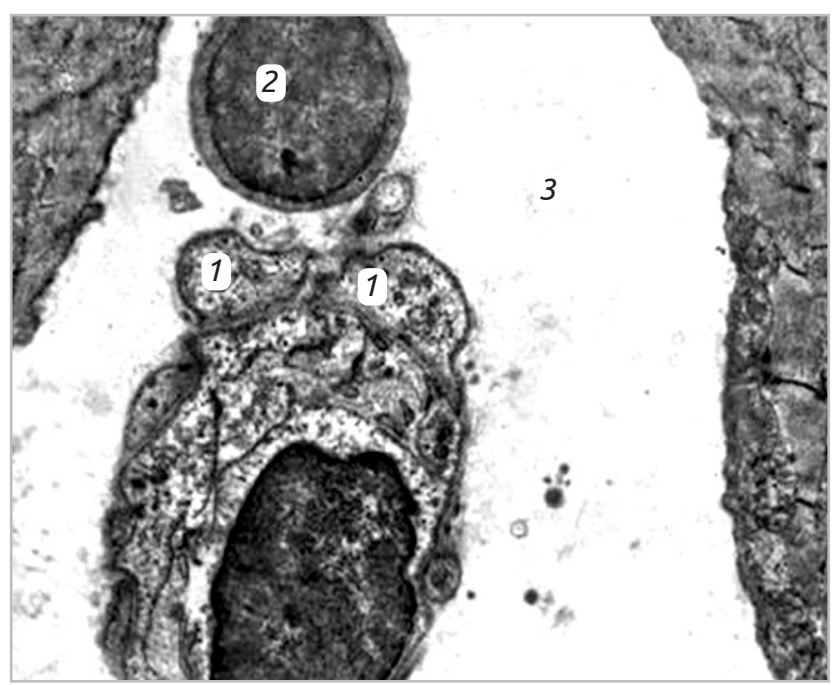

Позначення: 1 - набряклі ендотеліоцити; 2 - лімфоцит у периваскулярному просторі; 3 - розширений периваскулярний простір.

Рис. 1. Ультраструктура гемокапіляра скелетного м'яза задньої кінцівки щура. Реперфузія через 2 години, збільшення $\times 12000$.

Через 1 добу після зняття турнікета при електронномікроскопічному дослідженні ГМЦР скелетних м'язів задніх кінцівок щурів виявляли деструктивно змінені гемокапіляри зі стінками неоднакової товщини. Зберігалися виражений набряк ендотеліоцитів з їх пролабуванням у просвіт гемокапілярів (рис. 2), десквамація окремих ендотеліоцитів у просвіт мікросудин. У просвітленій цитоплазмі ендотеліоцитів переважали великі мікровезикули з дрібними множинними ділянками лізису. Окремі мітохондрії набряклі, з просвітленим матриксом і зруйнованими кристами. Канальці гранулярної ендоплазматичної сітки значно розширені, з рідкими рибосомами на стінках. Ядра ендотеліоцитів зберігали овальну форму, містили рідкісні поодинокі неглибокі інвагінації з добре контурованим перинуклеарним простором і частими ядерними порами. В ядрі домінує 
Огляди літератури, оригінальні дослідження, погляд на проблему, випадок з практики, короткі повідомлення еухроматин. Невелике ядерце сітчастої структури локалізується на периферії нуклеоплазми. Базальна мембрана контурується нечітко, окремі ділянки ії потовщені. Периваскулярні простори значно розширені. Довкола гемокапілярів виявлено екстравазати, які складалися з білкової субстанції та еритроцитів, що свідчить про підвищення проникності базальної мембрани.

Просвіт окремих гемокапілярів був заповнений цитоплазматичним детритом десквамованих клітин. Нерідко в просвіті судин поблизу ендотеліоцитів виявлялися тромбоцити, що свідчить про розвиток у ранньому реперфузійному періоді в гемокапілярах пристінкового мікротромбозу.

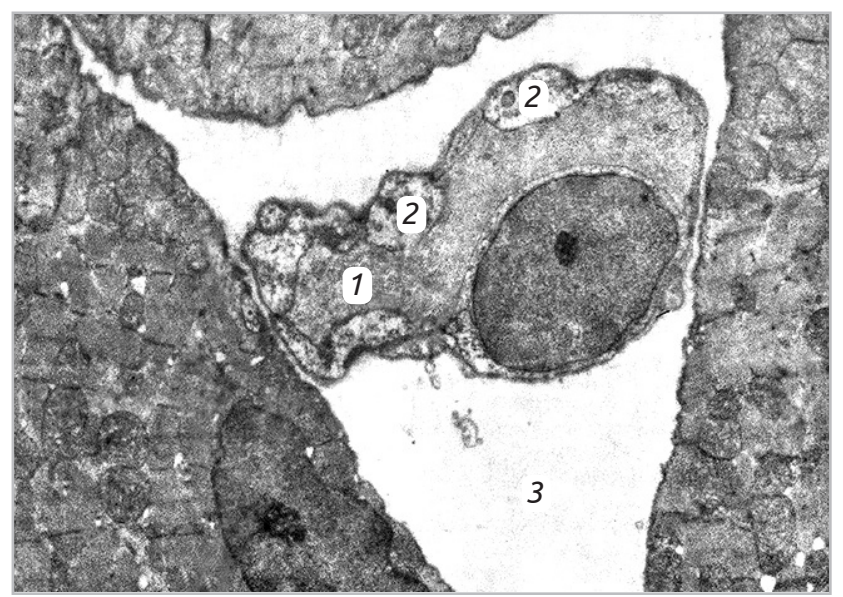

Позначення: 1 - деформований просвіт гемокапіляра; 2 - набряклі ендотеліоцити з пролабуванням у просвіт гемокапіляра; 3 - розширений периваскулярний простір.

Рис. 2. Ультраструктура гемокапіляра скелетного м'яза стегна задньої кінцівки щура. Реперфузія через 1 добу, збільшення ×13000.

Через 14 діб ішемічно-реперфузійного ураження ультраструктура ГМЦР скелетних м'язів кінцівок тварин у значній мірі відновлювалася. Гемокапіляри були правильної форми, їхня стінка збережена (рис. 4). На електронограмах виявлялися частково зміненої форми ядра ендотеліоцитів, їх ядерна оболонка мала інвагінації. Базальна мембрана незначно потовщена, дещо підвищеної електронної щільності, в перивазальному просторі виявлялися поодинокі лімфоцити.

Субмікроскопічний аналіз структури ГМЦР скелетних м'язів стегна задніх кінцівок щурів, проведений через 14 діб після зняття турнікета, показав, що набряк в ендотеліальних клітинах ще зберігається, проте його вираженість значно зменшилася, порівняно з попередньою групою тварин. Поряд із ядрами овальної форми і рідкими неглибокими інвагінаціями нуклеолеми виявляли ядра з глибокими і частими інвагінаціями, дрібнозернистою нуклеоплазмою та великим сіт-

При електронномікроскопічному дослідженні через 7 діб експериментальної ішемії-реперфузії, поряд з деструктивними явищами, виявляли також ознаки відновлення ультраструктури судин ГМЦР. У просвіті мікросудин у пристінковій ділянці подекуди були наявні тромбоцити. Відмічено помірний набряк ендотеліоцитів та лейоміоцитів. У просвіті передкапілярних артеріол і гемокапілярів та в екстравазальному просторі відмічали наявність збільшеної кількості лейкоцитів (рис. 3). Базальна мембрана артеріоли була збережена. В деяких ділянках вона була нечіткою, частково потовщеною, однак на більшому протязі їі структура збереглася.

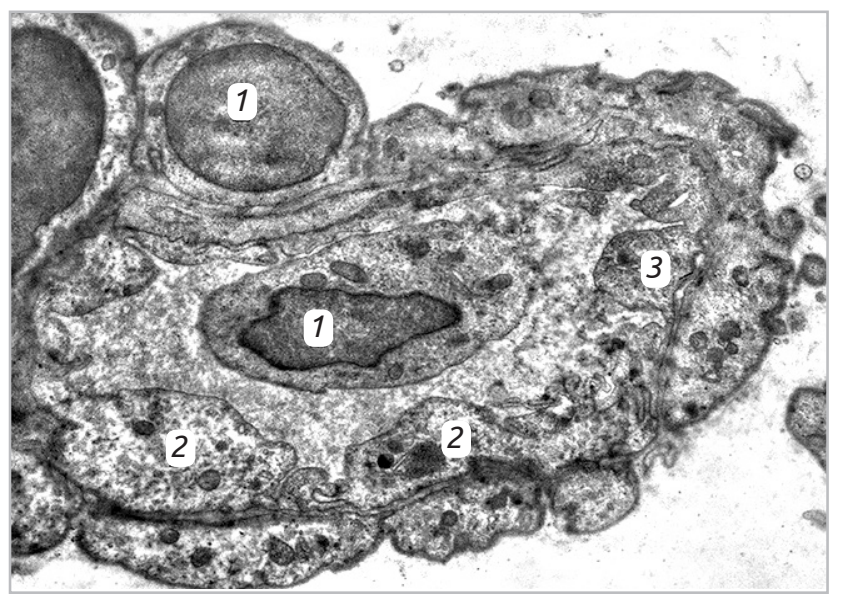

Позначення: 1 - лейкоцити; 2 - набряклі ендотеліоцити 3 незначним пролабуванням у просвіт мікросудини; 3 адгезований тромбоцит.

Рис. 3. Ультраструктура гемокапіляра скелетного м'яза стегна задньої кінцівки щура. Реперфузія через 7 діб, збільшення ×12000.

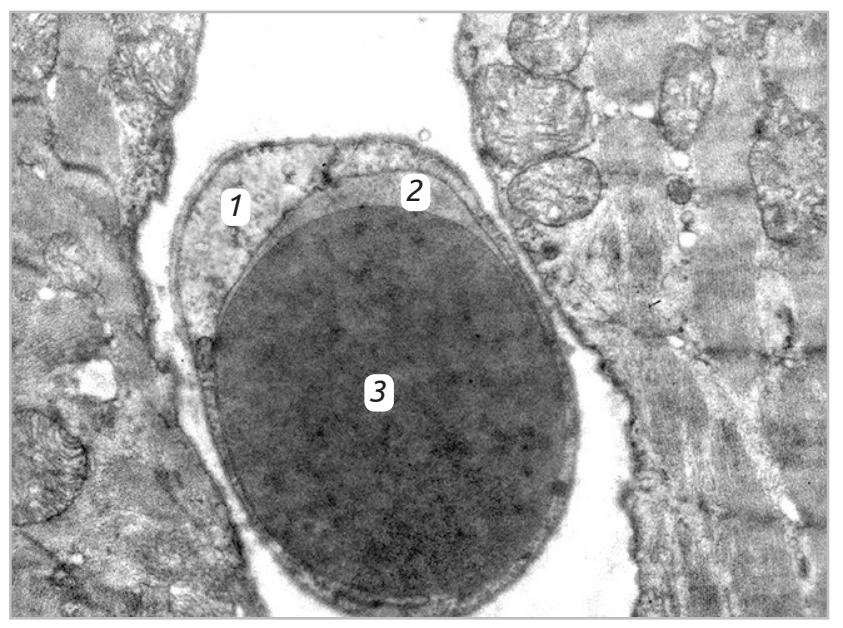

Позначення: 1 - периферійна частина ендотеліоцита; 2 просвіт гемокапіляра; 3 - еритроцит.

Рис. 4. Гемокапіляр скелетного м'яза стегна задньої кінцівки щура. Реперфузія через 14 діб, збільшення $\times 16000$. 
Огляди літератури, оригінальні дослідження, погляд на проблему, випадок з практики, короткі повідомлення частим ядерцем, локалізованим ближче до периферії ядра. Перинуклеарний простір і часті ядерні пори чітко контуровані (рис. 5).

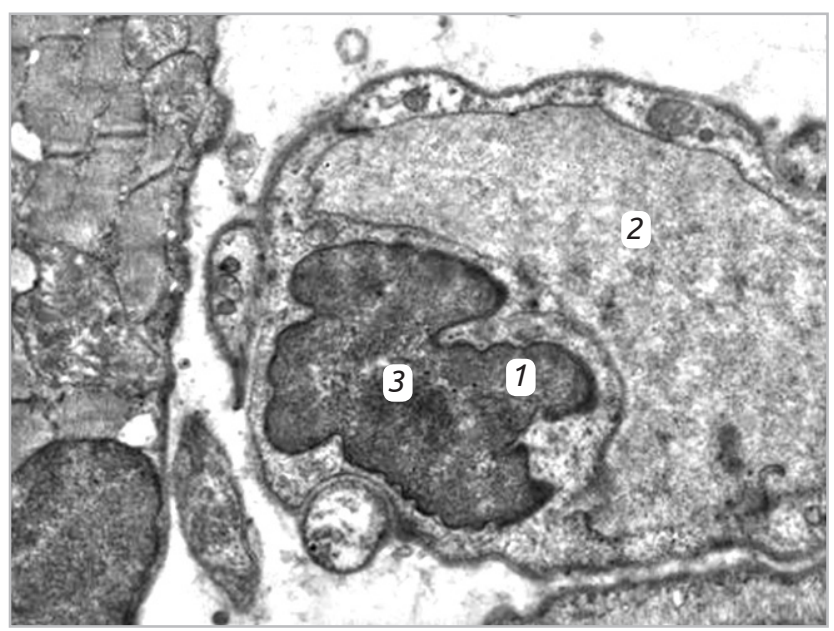

Позначення: 1 - ядро ендотеліоцита гемокапіляра неправильної форми за рахунок глибоких інвагінацій каріолеми; 2 - просвіт гемокапіляра; 3 - ядерце.

Рис. 5. Ультраструктура ендотеліоцита гемокапіляра скелетного м'яза стегна задньої кінцівки щура. Реперфузія через 14 діб, збільшення ×13000.

Мітохондрії крупні і дрібні овальної форми із матриксом нормальної електронної щільності та збереженими кристами, проте виявляли окремі великі мітохондрії із поодинокими дезорганізованими кристами і локальним просвітленням матриксу. Канальці ендоплазматичної сітки чітко контуровані, з множинними рибосомами.

У щурів у пізньому реперфузійному періоді субмікроскопічні зміни клітин ГМЦР значно зменшувалися, проте, порівняно з контрольними тваринами, навіть через 14 діб реперфузійного ураження все ще зберігалися помірно виражені зміни.

Висновки. 1. Ультраструктурні порушення у судинах ГМЦР ішемізованої м'язової тканини задніх кінцівок щурів спостерігались вже через 2 години після зняття турнікета і досягали макси-

\section{ЛІТЕРАТУРА}

1. Drew B. Application of current hemorrhage control techniques for backcountry care: Part one, tourniquets and hemorrhage control adjuncts / B. Drew, B. Bennett, L. Littlejohn // Wilderness and Environm. Med. - 2015. Vol. 26. - P. 236-245.

2. Вогнепальні поранення кінцівок : методичні рекомендації / О. А. Бур'янов, С. С. Страфун, І. П. Шлапак та ін. - К. : 2015. - 46 c.

3. Use of a tourniquet in total knee arthroplasty: a systematic review and meta-analysis of randomized controlled

мальної вираженості у щурів через 1 добу реперфузії, що підтверджує розвиток у них ішемічнореперфузійного синдрому.

2. При електронній мікроскопії в щурів раннього періоду експериментальної ішемії-реперфузії у судинах ГМЦР виявлено виражений набряк ендотеліоцитів із пролабуванням їх у просвіт гемокапілярів, ультраструктурні зміни внутрішньоклітинних структур ендотеліоцитів та їх ядер, нерівномірне потовщення та зміни електронно-оптичної щільності базальної мембрани, розширені за рахунок набряку периваскулярні простори із значною кількістю лімфоцитів у них, поява навколо гемокапілярів білкових та еритроцитарних екстравазатів, а також тромбоцитів у просвіті мікросудин на поверхні пошкоджених ендотеліоцитів, що свідчить про розвиток у гемокапілярах пристінкового мікротромбозу.

3. У пізньому реперфузійному періоді через 7 та 14 діб відбувався зворотний розвиток патологічних змін. У цей період ультраструктура судин гемомікроциркуляторного русла у значній мірі відновлювалася, гемокапіляри були правильної форми, їхні стінки збережені. На кінець експерименту виявлялися частково зміненої форми ядра ендотеліоцитів 3 інвагінаціями каріолеми, базальна мембрана мікросудин рівномірна, дещо підвищеної електронної щільності, в перивазальному просторі нерідко виявлялися поодинокі лімфоцити, що свідчить про те, що через 14 діб реперфузії повного відновлення ультраструктури судин ГМЦР все ще не відбувається.

Перспективи подальших досліджень. Отримані результати можуть служити основою для подальших досліджень ультраструктурного ремоделювання судин ГМЦР скелетних м'язів кінцівок при різних видах компресійної травми та при її поєднанні з іншими патологічними станами (крововтрата різного ступеня, краніоскелетна травма, опіки, дегідратація тощо), а також для оцінки ефективності застосування медикаментозної корекції ішемічно-реперфузійних порушень у м'яких тканинах кінцівки. 
Огляди літератури, оригінальні дослідження, погляд на проблему, випадок з практики, короткі повідомлення

6. Tennant D. The role of HIFs in ischemia-reperfusion injury / D. Tennant, N. J. Howell // Hypoxia. - 2014. Vol. 2. - P. 107-111.

7. Молекулярные механизмы развития и адресная терапия синдрома ишемии-реперфузии / О. А. Гребенчиков, В. В. Дихванцев, Е. Ю. Плотников [и др.] // Акту- альные вопросы анестезиологии и реаниматологии. 2014. - № 3. - С. 59-67.

8. Саркисов Д. С., Пальцев М. А., Хитров Н. К. О6щая патология человека / Д. С. Саркисов, М. А. Пальцев, Н. К. Хитров. - М. : Медицина, 1997. - 608 с.

\section{REFERENCES}

1. Drew B., Bennett, B., \& Littlejohn, L. (2015). Application of current hemorrhage control techniques for backcountry care: Part one, tourniquets and hemorrhage control adjuncts. Wilderness and Environm. Med., 26, 236-245.

2. Burianov, O.A., Strafun, S.S., \& Shlapak, I.P. (2015). Vohnepalni poranennia kintsivok: metodychni rekomendatsii [Inflammatory limb injuries: guidelines]. Kyiv [in Ukrainian].

3. Jiang, F., Zhong, H., Hong, Y., \& Zhao, G. (2015). Use of a tourniquet in total knee arthroplasty: a systematic review and meta-analysis of randomized controlled trials. J. Orthop. Scien., 20 (1), 110-123.

4. Henyk, S.M., \& Symchych, A.V. (2016). Reperfuziinyi syndrom pislia revaskuliaryzatsii ishemii nyzhnikh kintsivok [Reperfusion syndrome after lower limb ischemia revascularization]. Sertse $i$ sudyny - Heart and Vessels, 3, 104-108 [in Ukrainian].
5. Kutepov, D.E., Zhigalova, M.S., \& Pasechnik, I.N. (2018). Patogenez sindroma ishemii-reperfuzii [Pathogenesis of ischemia-reperfusion syndrome]. Kazanskiy med. zhurn. - Kazan Medical Journal, 99 (4), 640-644 [in Russian].

6. Tennant, D., \& Howell, N.J. (2014). The role of HIFs in ischemia-reperfusion injury. Hypoxia, 2, 107-111.

7. Grebenchikov, O.A., Dikhvantsev, V.V. \& Plotnikov, E.Yu. (2014). Molekulyarnye mekhanizmy i adresnaya terapiya sindroma ishemii-reperfuzii [Molecular mechanisms of development and targeted therapy of ischemiareperfusion syndrome]. Aktualnye voprosy anezteziologii $i$ reanimatologii - Urgent Issues of Anesthesiology and Resuscitation, 3, 59-67 [in Russian].

8. Sarkisov, D.S., Paltsev, M.A., \& Khitrov, N.K. (1997). Obshchaya patologiya cheloveka [General human pathology]. Moscow: Meditsina [in Russian].

\title{
УЛЬТРАСТРУКТУРНЫЕ ИЗМЕНЕНИЯ СОСУДОВ ГЕМОМИКРОЦИРКУЛЯТОРНОГО РУСЛА ЗАДНИХ КОНЕЧНОСТЕЙ КРЫС ПРИ ОСТРОЙ ИШЕМИИ, ВЫЗВАННОЙ НАЛОЖЕНИЕМ АРТЕРИАЛЬНОГО ТУРНИКЕТА
}

\author{
๑А. Т. Телевяк', П. Р. Сельский', И. Н. Клищ ${ }^{1}$, Р. С. Вастьянов ${ }^{2}$, О. Е. Кузив ${ }^{1}$,
} А. С. Вольская ${ }^{1}$, Х. И. Курило ${ }^{1}$, И. И. Боймиструк', Б. П. Сельский ${ }^{3}$

${ }^{1}$ Тернопольский национальный медицинский университет имени И. Я. Горбачевского Мз Украины годеский национальный медицинский университет

${ }^{3}$ Тернопольская университетская больница

РЕЗЮМЕ. Артериальные турникеты широко используются как в военной, так и в гражданской медицине (в частности при ранении конечностей, артро- и ангиопластике). Восстановление кровоснабжения конечности после снятия турникета можетвызвать ишемически-реперфузионные поражения как первично ишемизированных тканей, так и в отдаленных тканях и органах. Однако на сегодняшний день требуют более глубокого изучения ультраструктурные изменения тканей на местном уровне при ишемии-реперфузии.

Цель работы - исследовать состояние гемомикроциркуляторного русла задних конечностей крыс при острой ишемии и последующей реперфузии, вызванной наложением артериального турникета.

Материалы и методы. Было проведено электронномикроскопическое исследование сосудов гемомикроциркуляторного русла скелетных мышц задних конечностей 12 крыс в условиях экспериментальной острой ишемии. Контрольную группу составили 3 интактных животных. Острую ишемию вызывали путем наложения резиновых жгутов SWAT шириной 5-6 мм на задние конечности животных на уровне паховой складки в течение 2 ч под тиопентал-натриевым обезболиванием, а реперфузию моделировали путем снятия турникета. Исследование образцов мышечной ткани проводилось на кафедре гистологии и эмбриологии Тернопольского национального медицинского университета имени И. Я. Горбачевского с помощью электронного микроскопа ПЕМ-125K.

Результаты и их обсуждение. При электронной микроскопии скелетных мышц задних конечностей крыс в сосудах гемомикроциркуляторного русла обнаружены деструктивно измененные гемокапилляры со стенками неодинаковой толщины, выраженный отек эндотелиоцитов с пролабированием их в просвет гемокапилляров, десквамация отдельных эндотелиоцитов, утолщение базальной мембраны, расширенные вследствие отека периваскулярных пространств, скопление лимфоцитов в паравазальном пространстве, возникновение белковых 
Огляди літератури, оригінальні дослідження, погляд на проблему, випадок з практики, короткі повідомлення и эритроцитарных экстравазатов вокруг гемокапилляров. Нередко в просвете сосудов вблизи эндотелиоцитов визуализировались тромбоциты, что свидетельствует о развитии в гемокапиллярах пристеночного микротромбоза. Ультраструктурные изменения наблюдались уже через 2 часа после снятия турникета и были более выраженными через 1 сутки. В позднем реперфузионном периоде происходило обратное развитие патологических изменений, однако даже через 14 суток реперфузии полного восстановления ультраструктуры гемомикроциркуляторного русла все еще не происходило.

Выводы. Ультраструктурные нарушения в сосудах гемомикроциркуляторного русла ишемизированной мышечной ткани задних конечностей крыс достигали максимальной выраженности через 1 сутки после снятия турникета, что подтверждает развитие у экспериментальных животных ишемически-реперфузионного синдрома. В позднем реперфузионном периоде происходило обратное развитие патологических изменений.

КЛЮЧЕВЫЕ СЛОВА: острая ишемия; реперфузия; гемомикроциркуляторного русло; электронная микроскопия.

\title{
ULTRASTRUCTURAL CHANGES OF THE VESSELS OF THE HAEMOMICROCIRCULATORY BED OF HIND LIMBS OF THE RATS WITH ACUTE ISCHEMIA CAUSED BY ARTERIAL TOURNIQUET APPLICATION
}

\author{
@A. T. Televyak', P. R. Selskyy'1, I. M. Klishch'1, R. S. Vastyanov'², O. Ye. Kuziv'1, \\ A. S. Volska', Kh. I. Kurylo', I. I. Boymystruk', B. P. Selskyy ${ }^{3}$ \\ ${ }^{1}$ I. Horbachevsky Ternopil National Medical University \\ ${ }^{2}$ Odesa National Medical University, \\ ${ }^{3}$ Ternopil University Hospital
}

SUMMARY. Arterial tourniquets are widely used in both military and civil medicine (particularly in the case of limb injuries, arthroplasty and angioplasty). Restoring the blood supply to the limb after removal of the tourniquet can cause ischemic-reperfusion lesions of both the primary ischemic tissues and distant tissues and organs. However, the ultrastructural changes of tissues at the local level by ischemia-reperfusion are in need of deeper study today.

The aim of the study - to establish the condition of the haemomicrocirculatory bed of the hind limbs of rats with acute ischemia and subsequent reperfusion caused by the arterial tourniquet application.

Materials and Methods. The electron microscopic examination of the blood vessels of the haemomicrocirculatory bed of the skeletal muscles of the hind limbs of 12 rats under experimental acute ischemia was performed. There were 3 intact animals in the control group. Acute ischemia was caused by application of SWAT rubber bands on the hind limbs of animals, 5-6 mm width, at the inguinal fold level within 2 hours under thiopental anesthesia, and reperfusion was modeled by removing the tourniquet. The examination of muscle tissue samples was carried out at the Department of Histology and Embryology, I. Horbachevsky Ternopil National Medical University by using an electron microscope PEM$125 \mathrm{~K}$.

Results and Discussion. Electron microscopy of the skeletal muscles of the hind limbs of rats revealed in the vessels of the haemomicrocirculatory bed destructively altered hemocapillaries with unequal wall thickness, pronounced oedema of endothelial cells with their protrusion into the lumen of the haemocapillaries, desquamation of single endothelial cells, thickening of the basal membrane, enlarged by oedema perivascular spaces, accumulation of lymphocytes in the paravasal space, appearance of protein and erythrocytes extravasation around the haemocapillaries. Often in the lumen of vessels near the endothelial cells platelets were visualized, indicating the development in the haemocapillaries of microthrombosis near its wall. Ultrastructural changes were observed already within two hours after the removal of the tourniquet and were most pronounced after one day. In the late reperfusion period there was a reverse development of pathological changes, however, even after 14 days of ischemia-reperfusion the complete restoration of ultrastructure of haemomicrocirculatory bed still did not happen.

Conclusions. The ultrastructural disorders in vessels of the haemomicrocirculatory bed of ischemic muscular tissue of the hind limbs reached maximal expression in rats one day after the removal of the tourniquet, confirming the development in experimental animals of ischemic-reperfusion syndrome. In the later reperfusion period there was a reverse development of pathological changes.

KEY WORDS: acute ischemia; reperfusion; haemomicrocirculatory bed; electron microscopy.

Отримано 12.12.2019 